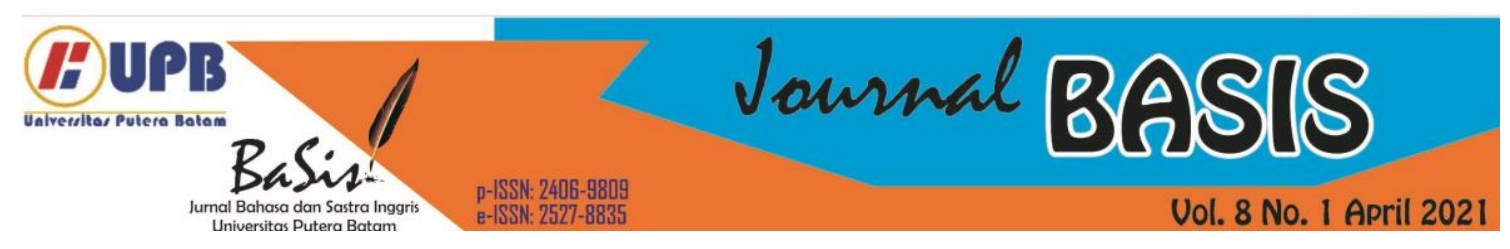

\title{
REPRESENTATION OF BANGKA BELITUNG'S WOMEN ON NOVELS WRITTEN BY BANGKA BELITUNG'S FEMALE AUTHORS: FEMINISIM STUDIES
}

\author{
Andri Fernanda ${ }^{1}$ \\ Universitas Bangka Belitung, Bangka, Indonesia \\ andrifernanda92@gmail.com \\ Ranto $^{2}$ \\ Universitas Bangka Belitung, Bangka, Indonesia \\ rantopalempat@gmail.com
}

\begin{abstract}
The goal of this study was to break down gender issues and stereotypes towards women constructed in Bangka Belitung society from the perspective of female authors. In analyzing the data, researchers carried out a qualitative descriptive method with feminist theory. The researchers also conducted critical discourse analysis on writings that have been published by Bangka Belitung's female authors. The results showed that there were still gender inequality and inferiority of women in society. The identity crisis faced by women when they are not married since marriage is seen as an ideal as well as a complement to their life as real women in society. On the other hand, the picture of how women had no rights over themselves was demonstrated in a situation when matchmaking and marriage were performed one-sidedly and suddenly, women did not have enough power to question these, even refused them. Besides, how strong a patriarchal system and culture was shaped by women, their closest people and the community was proven in the novels of the Bangka Belitung's female authors.
\end{abstract}

Keywords: Bangka Belitung, female authors, feminism, gender, literacy

\section{INTRODUCTION}

Literacy in Bangka Belitung now becomes the main priority. It is due to the rise of numerous reading movements coordinated by the provincial government, private agencies and even local groups in Bangka Belitung. As a wonderful spot, Bangka Belitung is one of the areas in Indonesia with a relatively low level of literacy. This fact, however, inspires a handful of millennials to commit and participate in the literacy movements that they are currently supporting. This is why literacy communities have arisen in recent years as great places for the youths who enjoy reading, writing, debating, honing, and increasing their reasoning abilities. Furthermore, the name Bangka Belitung itself has been revisited since the creation of a film directed by Riri Riza in 2008, adapted from a novel entitled Laskar Pelangi, written by Andrea Hirata, a Malay blood writer who was born in Belitung in 1967. The success of the film Laskar Pelangi led him and his birthplace to be popular. Surprisingly, instead of being famous for its literature, this popularity finally only introduced Bangka Belitung as a tourist attraction. The literary work itself is still being underestimated by the majority of local people. For this reason, groups are organized to promote discourse about the skills of the youths in literacy, particularly writing, to build the literate young generation. This is 
what then makes these communities play a vital role in the literary arena of Bangka Belitung.

Most members of the literary community in Bangka are not only local youths but also those from outside the city and the area. Moreover, most of them are students, university and college students, and workers currently living in Bangka. The existence of young writers from Bangka Belitung who publish articles individually or in groups (in the form of anthologies) gives a new breath in Bangka Belitung literacy. Uniquely, the writings of the young authors have a similar connecting factor which primarily discusses romance and religiosity, and most of them are narrated by female writers. In depicting the world in which women are involved, female authors portray it through the background of the story. The setting which is also known as the foundation relying on the general locale, historical time, and social circumstances in which its action occurs (Nurgiyantoro, 1995:216). It can be said that there are three main elements in the setting, namely place, time and social environment. In literary works, female authors cannot be normally isolated from the three critical aspects, which are consciously or not reflected in their writings. Concerning reality, the setting functions as an atmosphere and a metaphor. Nurgiyantoro (1995:241-243) again explains that the setting that serves as a metaphor is a setting that describes comparisons in connection with circumstance, atmosphere or something else that is indirectly related to the depiction of the women's world. Lia Shine and Annisa Fi Bi are now two productive female writers from Bangka Belitung. By exploring their works, this study tries to reveal how the representation of Bangka Belitung's women and the repetition which is consciously or unconsciously represented and narrated in their works.

\section{LITERATURE REVIEW}

In other scientific fields, such as economic, social, political and health perspectives, research related to women and Bangka Belitung has been very widespread, but the research associated with Bangka Belitung's women is still very limited in literature studies. One of the studies discussing Bangka Belitung's women in literary studies was Muhammad Roziqin's undergraduate thesis entitled Perempuan Pendulang Timah dalam Novel Padang Bulan Karya Andrea Hirata Suatu Pendekatan Psikologi Kepribadian in 2016. This research sought to explore the relationship between the structural elements in Andrea Hirata's novel Padang Bulan and the type of pragmatic values that represent the personality psychology of female characters.

Additionally, in 2019 Mulyanie Rozie, who conducted research titled Analisis Nilai-nilai Sosial dalam Kumpulan Cerita Rakyat Bangka Belitung in the journal Bina Bahasa Vol. 12 No. 2, also talked about literature in Bangka Belitung, but the focus was more on social values. In the composition, Rozie uncovered the social values contained in the collection of Bangka Belitung folktales arranged by Maulana Syamsuri with a sociological literary approach. This study found the values of affection, responsibility and life harmony.

So far, no research has attempted to discover how the representation of Bangka Belitung's women from the viewpoint of Bangka Belitung's female writers. Here, it can be inferred that most analyzes of Bangka Belitung literary works were done on the novels of Andrea Hirata. This study is 
therefore quite urgent in terms of literature study and feminism study in Bangka Belitung, especially in viewing how Bangka Belitung women represent themselves as Bangka Belitung women in their masterpieces.

\section{RESEARCH METHOD}

Adi (2011:243) states that the difference in applying research method emphasizes qualitative research that processes soft data in the form of words, photos and symbols and quantitative research that works on hard data represented in numbers. Meanwhile, in a broader sense, the method is viewed as a way or strategy in understanding reality through a systematic manner, namely there are steps to solve a causality. As a tool, the method is designed to simplify the problem, make it easier to solve and understand (Ratna, 2011:34). In line with the previously described problem and theoretical framework, the method applied in this study was a qualitative descriptive method in breaking down female stereotypes from the viewpoint of Bangka Belitung's female authors. The writer also divided the method into two stages, namely data collection and data analysis.

\subsection{Data Collection}

The method and techniques for data collection are essentially several methods or techniques which extend the human senses because the objective is to gather empirical data concerning research problems (Faruk, 2012:25). To solve the problem with theoretical concepts, descriptive methods, case studies and comparisons were applied to determine how the construction for women in Bangka Belitung was carried out and how it affected and was perceived by female writers. The data source collected were documents and field data, namely the writings of Bangka Belitung's female authors. The data or information obtained was then described in detail. After that, the writers made a comparison or evaluation of the data acquired from the works of female authors on the social realities that occur in society.

\subsection{Data Analysis}

According to Faruk (2012:25), the method of data analysis is a way to find relationships between data. The data collected were compiled systematically. Further, the relationship between the women depicted in the works of Bangka Belitung's female writers and the existing social realities was pinpointed by utilizing the correlational method to identify the relationship among the variables studied. The correlation method was used to assess the extent to which the variables in literary works were closely related to the empirical world and cultural construction in society. It was because the formation of literary works was based on logical relations from existing facts so that the construction of women in Bangka Belitung was derived from the perspective of Bangka Belitung's female writers based on the similarity and pattern repetition represented in their works.

\section{RESULT AND DISCUSSION}

Feminism focuses on sex as a principle that governs social life as a whole by power relations that subordinate women to men. (Barker, 2005:177). The feminism movement emerged in the 1980s and promoted gender equality and the pursuit of women's rights. Starting from such movements, feminism then strengthened itself into a different sort at an advanced stage, namely paradigmatic and theoretical. 
Feminism theory was subsequently utilized in various fields of science to reveal the position of women, one of which was in literary criticism. Ruthven (1984:32) says that literary criticism through a feminist approach or feminist literary criticism is used for a movement that voices and socializes feminist ideas for women's freedom. The theory of existentialist feminism is coined by Simone de Beauvoir, a French philosopher who becomes the motor of modern feminism, with his book Le Deuxième Sexe or The Second Sex in English. In his classic work, Beauvoir poses a big question about what the definition of woman is. According to him, women are defined based on the point of view and perspective of men. For him, women are not defined as men. The facts even show up in the form of writing where all the writings are written on the basis of the world of men so that there are so many difficulties in defining what women are (Beauvoir, 1953:46). This led to an agreement that women were always seen as objects or did not have their own existence, because a woman was believed to exist only if she had fulfilled the men's perspective and had been guaranteed by the men. This could be completely seen through the following quote:

\section{Annisa?" \\ "Beneran elo yang bernama Lady} Akhirnya cowok berkulit putih itu buka suara. Gayanya yang sok kegantengan membuat Lady ingin muntah. (Shine, 2017:3)

"Are you really Lady Annisa?"

Finally, the white boy spoke to her. His handsome style made Lady want to vomit. (Shine, 2017:3)

In the novel Terpaksa Menikah by Lia Shine, it can be generated how Lady
Annisa, a woman who received discriminatory treatment from Alvend, first met him and was picked up at the airport. Alvend's treatment of Lady Annisa seemed very cynical. As we know, ethical and cultural construction should be maintained as a social being when we meet people for the first time, but from Alvend's treatment of Lady, there was a clear imbalance between men and women. The above quote illustrates that men are depicted as being superior. This is then reaffirmed when Alvend did sexism against Lady Annisa. It occurs when Lady Annisa introduced herself to emphasize that she was really Lady Annisa; the woman Alvend had to pick up at the airport.

"Duhh.. Gila! Judes banget nih bocah, tidak sesuai dengan nama. Namanya sih, cewek banget tapi dari cara bicara dan cara berpakaian ia lebih mirip preman pasar," batin Alvend. (Shine, 2017:3)

"Damn! How cruel she is, not match with the name. Her name is a really girl, but from the way she talks and the way she dresses, she looks more like a market thug," thought Alvend. (Shine, 2017:3)

The quote above clearly explains how patriarchal thinking is attached to the character Alvend and represented by how he associates the name Lady Annisa with the feminine image that should be owned by women. Patriarchy and femininity dogma are shown clearly, that women must be gentle, polite, compassionate, restrained and follow other existing rules. This will be a problem when the woman does not follow these standards or even adopts the opposite. Considering the sexism contained in the quotation, when Alvend asked whether the woman was 
Lady from Bangka Belitung that he had to pick up with an arrogant tone and then Lady replied with a curt answer, Alvend was spontaneously shocked and assumed that she was irrational. More than that, he also equated and identified Lady's way of speaking and way of dressing with market thugs, men who had no job and usually committed crimes, such as extortion and anarchism. Indeed, the equation made by Alvend to Lady seems to be far away, even very lame. The comparison clearly demonstrates that if a woman does not pay attention to feminine elements (even on a small scale, such as how to dress and how to speak) then she is matched with an uneducated man who has the potential to commit crimes.

Another thing exemplified how Alvend treated Lady. When she arrived at Alvend's house and lived together, Alvend, who held a patriarchal mindset, handled Lady like a pet. Lady then seemed to have no rights over herself and like women in the male mindset, she must be in the domestic space.

Hari ini Lady ingin sekali keluar rumah. Terserah ke mana, ia bosan di rumah terus. Tapi, bagaimana caranya, ia sama sekali buta Jakarta. Ia juga belum punya teman buat diajak jalan. Karena setelah mendaftar kuliah kemarin dan mengikuti ujian masuk, Alvend sama sekali tidak membiarkannya keluar. Setelah mereka masuk ke dalam rumah, Alvend pasti langsung mengunci seluruh pintu, sedangkan ia pergi keluar. Rasanya Lady ingin kabur saja, tapi mau kabur ke mana. (Shine, 2017:7)

Today Lady wanted to leave the house. Whatever, she was bored at home. But, how could she do it, she completely not know about Jakarta. She also had no friends to go out with. Because after registering for college yesterday and taking the admission test, Alvend did not let her out at all. After they entered the house, Alvend must have immediately locked all the doors, while he went outside. It felt like Lady wanted to run away, but where did she want to run. (Shine, 2017:7)

Alvend as a man has the freedom to be in the domestic space and the public space. He also has the legitimacy to monitor whether Lady can leave or not, so what happens is that Lady is stuck in the domestic space while Alvend is free to explore the public space at will. This restriction has for a long time been battled by feminists who believe they are only trapped in the domestic space that only exists in their houses. Alvend's control is crueler in this novel. He is not only prohibited but also followed by locking the doors in the house. Here, Lady is represented as not much apart from a pet or property. Nevertheless, Alvend is not a family or even the husband of Lady Annisa. He is only the son of a friend of Lady's mother who lives in Jakarta. Unfortunately, he has absolute authority over Lady.

Lady is a representation of Bangka Belitung's women depicted in Lia Shine's novel Terpaksa Menikah. It pertains to how the social culture of society also shapes women through values that must be understood and implemented by women themselves so that they are accepted in society. Although she leaves for and has education outside Bangka Belitung, these values are still adopted and attached. One of them is marrying the choice of her parents. Here, it is shown that a woman does not even possess the authority over herself in choosing her life partner. 
"Terserah kalian mau ribut sampai malam atau sampai subuh sekalian, yang penting minggu depan kalian harus menikah." Mami menatap keduanya secara bergantian......

"Kalau kamu tidak percaya, kamu bisa tanyakan hal ini pada ibumu langsung. Tante hanya menyampaikan pesan keluarga besar kamu di Pangkal Pinang." (Shine, 2017:20)

"It is up to you to have a quarrel until evening or dawn, the important thing is that next week you both have to get married." The mother looks at the two in turn....'If you don't believe it, you can directly ask your mother about this. Auntie only conveyed the message of your family in Pangkal Pinang." (Shine, 2017:20)

The quotation above clarifies that Lady was shocked after being forced by Alvend's mother to get married imminently. At that time, Lady's mother did not communicate this thing to Lady first, but directly through Alvend's mother. Lady did not have the choice to choose, even that choice was never given to her. This also made Lady confirm directly to her mother in Bangka Belitung related to the sudden issue of marriage. This was also irritating her while she was not hearing the news directly from her family's mouth, but from Alvend's mother, which incidentally was the mother of Lady's future male partner later. It was quite surprising when Lady confirmed to her mother regarding her sudden marriage that she got from someone else. Instead of apologizing to Lady for what happened, Lady's mother brought up the big problem by reminding Lady about the permission she gave to her to take education outside Bangka Belitung and the fees to pay it. Lady's mother also threatened that if Lady intended to quit college due to an arranged marriage, then Lady must give compensation to her mother.

... Seperti yang sudah Lady duga, ibu mengungkit masalah Lady yang memaksa ingin kuliah di Jakarta. Kalau waktu itu Lady lebih memilih kuliah di Bangka, mungkin ia tidak akan menikah secepat ini. Lady tidak bisa berkutik, apalagi ibu meminta uang ganti rugi kalau lady berhenti kuliah. Nominalnya tidak tanggung-tanggung, tiga puluh juta. (Shine, 2017:23)

...As Lady expected, mother brought up Lady's request to study in Jakarta. If at that time Lady had chosen to study in Bangka, maybe she would not have gotten married soon. Lady could not move, especially when the mother asked for compensation if Lady stopped college. The nominal was thirty million. (Shine, 2017:23)

Here, it is presented how Lady is regarded as a commodity, especially in matters relating to her life and future. Lady does not have the power and legitimacy over herself, even when she tries to question it, her mother discusses Lady's intention to study in Jakarta which has been accommodated by her parents. She then threatens Lady if her daughter dares to do useless things related to marriage or stop the education, she must provide compensation for all costs that her parents already spent to finance her college. What Lady has done hasn't even reached the stage of suing, only at the stage of confirmation. Suing is impossible for Lady to do, so Lady really has no other choice but to follow the will of her family. Lady tries to talk 
about this occasion to Deska, her close friend. She thinks that maybe after she tells the problem that happens to her, Deska may provide a way out or at least a bright solution to the Lady's problem, which is currently at a dead end. However, instead of providing a good solution, Deska unexpectedly makes the deadlock clearer for Lady. This can be found in the following quote:

"Kapan lagi sih Lady, kamu dapat suami seganteng itu. Mau cari ke lubang semut pun nggak bakalan dapat. Cowok-cowok ganteng zaman sekarang udah pada musnah apa lagi buat cewek-cewek nggak jelas kayak kita," cerocos Deska saat Lady menelpon siang tadi. (Shine, 2017:24)

"When, Lady, can you get such a handsome husband. Even if you want to seek for him in the ant hole, you will not get it. Handsome boys in this era are gone, what's more for girls like us," said Deska when Lady called this afternoon. (Shine, 2017:24)

Deska even emphasizes the position of women's inferiority to Lady when she describes Alvend as a perfect future partner, a man who was arranged for Lady. Deska reaffirms the position of women as the inferior, substandard and helpless by describing Lady and herself as "cewek nggak jelas kayak kita". For Deska, Alvend is a physically handsome and attractive guy, an ideal dream for women at present. The rejection of an arranged marriage created by Lady is something nonsense to Deska, instead of watching Lady as a victim who is forced to marry a stranger. Deska says Lady should be grateful for what happened to her. Moreover, Deska even blames Lady for her complaints.
"Duh, semenderita apa, sih? Ibu Maryana kali yang harus menderita akibat ulah anak gadisnya yang sulit diatur. Kalo aku jadi kamu, aku nggak akan nolak sama pilihan orang tua. Karena orang tua nggak mungkin milih orang yang salah buat kita. Percaya, deh." Deska malah menceramahinya. (Shine, 2017:24)

"Oops, How suffering are you? It must be mother Maryana who suffers because of the unruly behavior of her daughter. If I were you, I would not refuse the parents' choice. Because parents cannot possibly choose the wrong person for us. Trust me." Deska even lectured him. (Shine, 2017:24)

Deska also questions the suffering that happens to Lady who is forced to marry by reversing the fact that the person who is supposed to suffer is Maryana, Lady's mother because she possesses a daughter who is difficult to control. Besides, Deska places parents as people who are always right, who have the right to decide the best for her life, and who never make mistakes. Thus, even though the choice created by the parents is disliked or even painful to the child, it is the best selection and the child must accept the decision, like it or not. That is represented in the following quote:

"Suatu saat kamu akan berterima kasih sama ibumu dan maminya Alvend karena telah menjodohkan kalian," ujar Deska sebelum mengakhiri percakapan. (Shine, 2017: 25)

"One day you will thank your mother and Alvend's mother for making you a match," said Deska 
before ending the conversation. (Shine, 2017: 25)

Women and marriage became quite central issues discussed in novels written by Bangka Belitung's female authors. Not only was Lia Shine's novel Terpaksa Menikah that touched the problem of marriage, but there was also a novel composed by Annisa $\mathrm{Fi} \mathrm{Bi}$ in 2017 which talked about the same thing, and even had a similar pattern. The interesting topics related to relationships and marriage in the story written by Annisa Fi Bi could be directly identified from the title Kutemukan Kamu di Peradaban Waktu. The main character involved a teenage girl, almost similar to the character of Lady in Lia Shine's novel Terpaksa Menikah. The difference is that the main character in Kutemukan Kamu di Peradaban Waktu was described as a quite religious young woman because she lived and grew in a religious and conservative family. She was Fatimah Az-Zahra, or often called by the nickname Fati. With a background similar to Lia Shine's novel Terpaksa Menikah, the story began with the graduation of the main character's from high school and then the plot continued highlighting the viewpoint of the first person on her path to pursue higher education at university as well as the twist and turn of her love journey. Marriage in adolescence seemed to be a natural occurrence where marriage problems were also raised and repeated as something common to Annisa Fi Bi. In her novel, she represented how Fati was destroyed due to the failure of her marriage that had been planned because the man had impregnated another woman. It implies how men are very superior and women are seen as mere objects.
"Maaf, aku harus menikahi perempuan yang sudah mengandung buah hatiku." Tanpa rasa bersalah semakin mantap pergi meninggalkan gadisnya. ( $\mathrm{Fi}$ $\mathrm{Bi}, 2017: 22$ )

"Sorry, I have to marry a woman who already contains my baby." Without guilt, the man was more determined to leave her girl. ( $\mathrm{Fi} \mathrm{Bi}$, 2017:22)

The quote above demonstrates that there was not even the slightest sense of guilt from Fati's future partner, although all kinds of preparations, from the wedding invitations that had been spread to the wedding costs that had been paid in full, were nearly complete. In another part, it was written that another man came and approached Fati to make her become his girlfriend, but he was refused because apart from having a religious and conservative way of thinking, Fati remembered her bad memories about marriage. Instead of being rejected, the man then asked her to marry him. Here, it becomes ever clearer and thicker that marriage may be easily promised and also easily canceled and the man has the authority over it.

"Ya udah, kita nikah!" Satu hal
yang paling ia benci adalah
pernikahan. Batinnya seakan sudah
mati rasa. Dulu, ia sempat dilamar
saat semester satu, tapi kandas. (Fi
$\mathrm{Bi}, 2017: 30$ )
"Alright, we got married!" One
thing she hated the most was
marriage. Her mind seemed to have
gone numb. In the past, she was
proposed in the first semester, but
failed. (Fi Bi, 2017:30)

However, Fati's desire to get married was still very strong. In almost all the novels of Bangka Belitung's female writers, it can be said that 
marriage is a way to raise the position of women as well as a hopeful moment. Marriage for women is not only a fulfillment of desires but also a way to increase stratification and provide the feeling of the real women. In this novel, it was also illustrated how Fati had the greatest wish, namely being proposed by a man. We can note how patriarchal culture enters the minds of women to the subconscious level, which emphasizes the women's inferiority in society.

Laki-laki yang pernah disinggung mirip om-om itu dengan gampangnya telah memporakporandakan hidup Fati. Segampang itu dosen kece melamarnya, apa seperti itu lamaran baik dan benar? Oh, ia malah pernah bermimpi akan dilamar dengan kesungguhan. (Fi Bi, 2017:45)

The man who was once said to resemble the mature man easily ruined Fati's life. It was that easy for a cool lecturer to apply for it, is that a good and true proposal? Oh, she even dreamed that he would be proposed in earnest. (Fi $\mathrm{Bi}$, 2017:45)

Marriage is represented as the dream of Bangka Belitung's women, even is considered as self-fulfillment. As a result, unmarried women will suppose to be weird and they are even ostracized in the family and society. The same problem is also provided by Lia Shine's sequel novel entitled Mengejar Jodoh. The main character in this novel was still a woman, a 30-yearold single career woman named Flowrin. She felt inferior and ashamed because at the age of 30 she has not been married yet. She then received questions from her family and people around her regarding her single status. Her desire to get married went to the subconscious, not just dreaming as represented in the novel of Annisa Fi Bi. Flowrin even experienced a blurring of identification between the subconscious and the empirical world.

Mata sipit Flowrin fokus menatap layar laptop di depannya, tetapi pikirannya melayang kesana kemari. Perempuan berkulit putih itu masih tidak habis pikir dengan mimpi yang ia alami tadi malam. Semua itu terlalu nyata untuk dikatakan sebagai mimpi. Menikah. (Shine, 2019:7)

Flowrin's narrow eyes focused on staring at the laptop screen in front of her, but her thoughts were daydreaming. The white woman still could not stop thinking about the dream she had last night. All things were too real to be dreams. Married.

(Shine, 2019:7)

Like Lady and Fati, Flowrin is indeed a picture of women from Bangka Belitung. This then became natural when the characters Lady and Fati in two different novels ended up getting married at a young age, either because of their own wishes or because of an arranged marriage from their parents. Discussions about marriage have become commonplace at the age of high school graduates who have not turned twenty yet because if they are still single, they will get insinuations, talks or unpleasant treatments from their closest people. Flowrin is a prime example of what is difficult to do. At the age of 30, Flowrin continues to be judged on marriage-related questions discrediting her. 
Jujur saja, Flowrin mulai jenuh dengan serentetan pertanyaan horror 'kapan nikah?' yang menghantuinya beberapa tahun terakhir. Demi Tuhan, ia juga ingin menikah. Bagaimana ia bisa menikah, jika sampai sekarang belum ada laki-laki yang datang ke rumah untuk melamarnya. (Shine, 2019:8)

Frankly, Flowrin was getting tired of the series of horror questions "when to get married?" That haunted her the last few years. For God's sake, she wanted to get married too. How can she get married, if until now no man has come to the house to propose to her. (Shine, 2019:8)

The inferiority and subordination that occur in women are displayed in this study. The patriarchal way of thinking slowly creeps through the marriage institution. Therefore, when a woman is not married yet, she will get such a cynical view from society. She will be persistently questioned, haunted, and pressured by her closest people. Observing Flowrin's case, the main character cannot even do anything, except for a proposal from men. This is a representation of Bangka Belitung's women represented in the writings of Bangka Belitung's female authors. It can be concluded that the issues of early marriage and women's inferiority in Bangka Belitung are still very thick. The three novels reflect how the patriarchal system functions in the lives, culture and dogmas of the people of Bangka Belitung.

\section{CONCLUSION}

The writings of Lia Shine and Annisa Fi Bi were compositions that represent Bangka Belitung's women from the viewpoint of Bangka
Belitung's female authors. According to the results, how gender issues and stereotypes towards women constructed in the Bangka Belitung society depicted inferiority. Women stood for second class gender and had no power and effort over themselves. It was reflected in Terpaksa Menikah by Lia Shine and I Found You in the Civilization of Time by Annisa Fi Bi. Both addressed the issue of marriage. Setting a young woman to be the main character, Lia Shine tried to clarify the status of a woman forced to marry as a consequence of her mother's arranged marriage. Even though the young woman just verified the tidings to her mother, what happened then was her mother actually warned Lady, the main character, not to forget the given permission for her to study in college. His mother even threatened that if she dared to commit awful things, such as dropping out of college, then she had to pay compensation for the tuition fees to her parents.

Meanwhile, with the same background and character Annisa Fi Bi presented how a young woman wanted to marry, a woman who just graduated from high school, but later the big day was canceled because her future husband had impregnated another woman and he did not feel guilty about making the sin. Further, during her journey, Fati as the main character met a few men who easily said they wanted to marry her - as if marriage is a male trivial affair, but for women, it becomes something to dream of. This was demonstrated by the fact that Fati explained that she had long wished to be proposed sincerely and to get a marriage - even the wish has been settled in the main character's dream for a long time ago.

In the next novel Mengejar Jodoh, Lia Shine remained to hire a woman to 
be a central character in her novel. Unlike Terpaksa Menikah, in this novel, Lia Shine showed how the main character, a career woman, had a dilemma, again and again about marriage. How questions, talks and sarcasm from the closest people and society continued to haunt the woman occurred because of her single status. The space between the empirical world and dream world is even blurred when Flowrin realized that it was hard to identify the time and space when she dreamt of being proposed and married.

Marriage is considered as women's self-fulfillment which is expected and aspired. Conversely, there are many betrayals in taking this path, all of which are represented by men. Then, it is inevitable that there is also compulsion from family or closest people to get married that cannot be refused, even just to be questioned by women.

\section{ACKNOWLEDGEMENTS}

We gratefully thank the Ministry of Research dan Technology of the Republic of Indonesia/National Research and Innovation Agency, Deputi Bidang Penguatan Riset dan Pengembangan, for financial support under the scheme of Penelitian Dosen Pemula (PDP) 2020.

\section{REFERENCES}

Adi, I. R. (2011). Fiksi popular teori dan metode kajiannya. Yogyakarta: Pustaka Pelajar.

Barker, C. (2005). Cultural studies: Theory and practice. Australia: Sage Publications.

Beauvoir, S. De. (1956). The second sex. London: Lowe and Brydone (Printers) Ltd.

Budiati, A. C. (2010). Aktualisasi diri perempuan dalam sistem budaya jawa (Persepsi perempuan terhadap nilai-nilai budaya jawa dalam mengaktualisasikan diri). Jurnal Pamator, 3(1), 51-59.

Faruk. (2012). Metode penelitian sastra. Yogyakarta: Pustaka Pelajar.

Fi Bi, A. (2017). Kutemukan kamu di peradaban waktu. CV Syifah Group.

Nurgiyantoro, B. (1995). Teori pengkajian fiksi. Yogyakarta: Universitas Gadjah Mada.

Ratna, N. K. (2011). Teori, metode, dan teknik penelitian sastra dari strukturalisme hingga postrukturalisme perspektif wacana naratif. Yogyakarta: Pustaka Pelajar.

Ruthven, K. K. (1984). Feminist literary study: An introduction. Cambridge University Press.

Shine, L. (2017). Terpaksa menikah. Penerbit Hanami.

Shine, L. (2019). Mengejar jodoh. Penerbit Hanami. 
